\title{
Relationship of footwear comfort, selected size, and lower leg overuse injuries among infantry soldiers
}

Darja Nesterovica ${ }^{*}\left[0\right.$, Normunds Vaivads $^{2}$ and Ainars Stepens ${ }^{1}$

\begin{abstract}
Background: High rates of musculoskeletal injuries such as plantar fasciitis and stress fractures have been observed among physically active military personnel. During service time, infantry soldiers use issued boots daily that should fit well and provide comfort to prevent injuries and decrease lower extremity pain effectively. The association of military boot comfort with overuse injuries remains unclear. This study investigates the relationship between the chosen military boot size, perceived boot comfort and lower leg overuse injury.

Methods: During the cross-sectional study, 227 (males, $n=213$; females, $n=14$ ) active-duty infantry soldiers at a mean age of 29.5 years old, and with an average service time of 7.2 years were assessed for a history of overuse injury, footprint length, appropriate shoe size, and footwear comfort. Males with a history of overuse injury $(n=32)$ and noninjured age-matched controls $(n=34)$ were selected for detailed testing and establishing the possible relationship between footwear comfort and lower leg overuse injury.

Results: No relationship was found between footwear comfort and a history of lower leg overuse injury. $N=38$ (57.6\%) of study subjects were wearing an inappropriate shoe size daily. Inappropriate shoe size usage affected footwear comfort ratings significantly.
\end{abstract}

Conclusions: Study results showed that improper boot size was significantly related to comfort ratings but was not associated with a history of lower leg overuse injury.

Keywords: Military personnel, Footwear comfort, Overuse injuries, Military boot

\section{Background}

Most military personnel require high physical demands during service time. It has been reported that $41-67 \%$ of sustained injuries in the military affect the lower extremities [1-3]. Typical injuries associated with physical training and prolonged load carriage are cumulative micro-traumatic lower extremity overuse injuries [4]. Injuries such as stress fractures, shin splints, patellofemoral pain, plantar fasciitis, and Achilles tendinopathy

*Correspondence: darja.nesterovica@rsu.lv

${ }^{1}$ Military Medicine Research and Study Centre, Rīga Stradiņš University, 14 Baložu Street, Riga LV-1048, Latvia

Full list of author information is available at the end of the article reduce military readiness and could even be a reason for medical discharge $[5,6]$. This study explores military boot comfort and its relationship with musculoskeletal overuse injury in detail.

During training or actual combat scenarios, military personnel use military boots that protect the shank and foot from environmental hazards such as irregular and uneven terrain. Foot health and footwear comfort are crucial for the military readiness of infantry soldiers. Shock absorbance and stability on uneven terrain are also very important military footwear features. Footwear shock-absorbance study results among Israeli infantry recruits showed that soldiers who used basketball shoes during basic training had a lower incidence of overuse original author(s) and the source, provide a link to the Creative Commons licence, and indicate if changes were made. The images or other third party material in this article are included in the article's Creative Commons licence, unless indicated otherwise in a credit line to the material. If material is not included in the article's Creative Commons licence and your intended use is not permitted by statutory regulation or exceeds the permitted use, you will need to obtain permission directly from the copyright holder. To view a copy of this licence, visit http://creativecommons.org/licenses/by/4.0/. The Creative Commons Public Domain Dedication waiver (http://creativeco mmons.org/publicdomain/zero/1.0/) applies to the data made available in this article, unless otherwise stated in a credit line to the data. 
injuries of the foot (18\%) than those who wore infantry boots (34\%). The authors of the study concluded that the basketball shoes' shock attenuation reduced foot overuse injuries, but not injuries at other lower extremity locations [7]. Other studies showed that military footwear specifically made for prolonged standing and marching, adverse weather conditions, and with a proper fit may effectively prevent injuries and decrease lower extremity pain $[8,9]$.

Footwear comfort is a complex combination of several factors including good fitting, internal temperature, humidity environment, plantar pressure distribution, and ground impact force [10-12]. As reported by a recent systematic review, a large proportion of the population wears ill-fitting shoes that contribute to foot pain and foot disorders [13]. Research evaluating shoe sizing on the subjective fit and comfort of shoes is encouraged [14]. Pressure-induced skin lesions and toenail problems are clinical effects of poor-fitting or uncomfortable footwear observed in the general population, especially those with chronic foot disorders $[15,16]$. Footwear comfort has been proposed as an important factor for all movementrelated lower extremity injuries $[17,18]$. Associations of chronic foot disorders (e.g., pes planus, hallux valgus) and acute injuries (ankle fracture or sprain) with boot usage among military populations, as well as military boot functional needs were established previously [19, 20]. This study compares the used infantry boot size (subjective fit) with correct fit according to bare footprint length among infantry soldiers with and without a history of lower extremity overuse injury.

\section{Methods}

We carried out a study designed in two stages: stage I cross-sectional study and stage II case-control study. Flow chart of the study design is seen in Fig. 1.

In 12 consecutive interview sessions total, 228 (16\%) of all active-duty infantry soldiers of Latvian Land Forces (males, $n=214$; females, $n=14$ ) were invited to participate in our study during the annual medical check-up at the Latvian National Army Logistic Command Military Medical Support Centre. Participation was voluntary, and the study results did not change the annual medical check-up results. Before entering the study, written informed consent was provided for each potential study participant; one person did not sign the informed

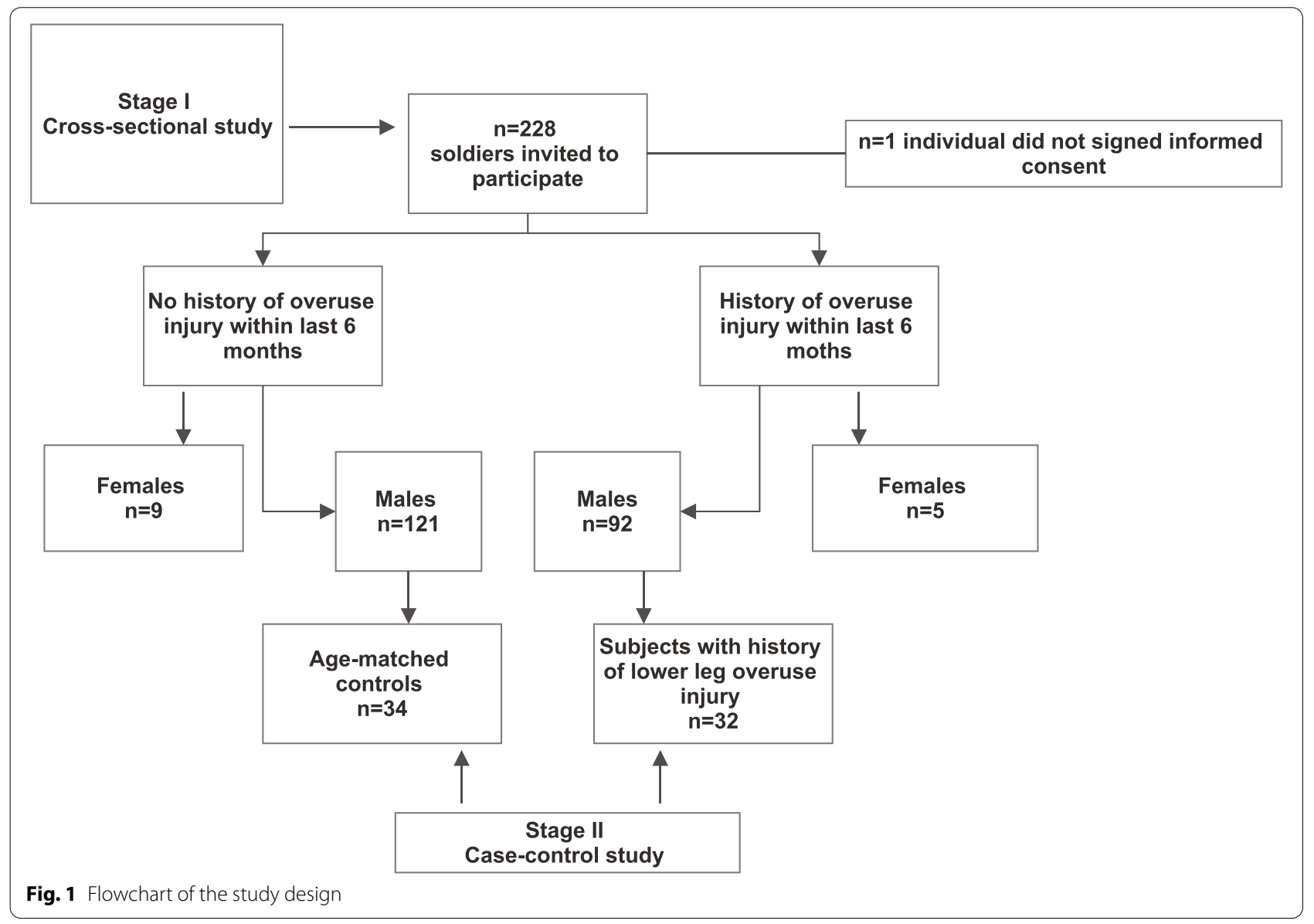


consent, and according to the protocol, 227 infantry soldiers were selected for further activities. Their mean age was $29.5 \pm 7.1$ years old (range $20-49$ years), service time $7.2 \pm 6.4$ years (range 0.5-25years). Study population characteristics are shown in Table 1.

The musculoskeletal injury was considered if soldier either reported or had a medical record of injury, which did not allow participation in at least one activity during the last 6 months of service. Musculoskeletal injuries were classified into two groups: acute and overuse injuries and the coding was performed by the interviewer (DN). The acute injury was defined as an injury due to blunt, crushing, penetrating trauma. Acute injuries are strains, sprains, ligament ruptures, fractures [excluding stress fractures] and were classified by ICD-10 (International Classification of Diseases, Tenth Revision) codes S00-T32 [21]. Overuse injuries were defined as injuries caused by repetitive or forceful tasks resulting from repeated overstretching or overloading [22]. Injuries such as anterior or posterior tibial syndrome (ICD-10 code M76.8), plantar fasciitis (M72.2), Achilles tendonitis (or bursitis, M76.6), peroneal tendinitis (M76.7), and stress fractures (M84.3) were classified as overuse injuries. For both types of injury, body regions were classified in the same manner as in the Barell injury matrix [23].

For this study, we have prepared a military comfort assessment tool according to the previously used methodology [24]. A visual analogue scale with a tencentimetre length was used to rate the footwear comfort for six dimensions: overall comfort, forefoot cushioning, arch cushioning, heel cushioning, arch support, heel support, according to a previously used method. The left end was labelled as 'not comfortable' (0) and the right end was labelled as 'best comfort' (10). Example is shown in Additional file 1.

For the second stage of our study, we have invited all $32(14 \%)$ subjects with a history of the lower leg, ankle, and foot overuse injury and 34 (15\%) age-matched noninjured subjects for more detailed testing. Visual inspection of the skin and nails of the foot and bare footprint length were additionally assessed. The presence of blisters, corns, or calluses, as well as ingrown toenails and subungual haematoma, were documented according to the classification by Carr\&Cropley [25]. Characteristics of the case-control study population are shown in Table 2.

For footprint length assessment, participants were asked to stand in a relaxed manner on a pressure platform $(2 \mathrm{~m} \times 0.4 \mathrm{~m} \times 0.02 \mathrm{~m}$, RSscan International, Belgium). Platform calibration was performed before each measurement. Plantar pressure analysis software (Foots$\operatorname{can}^{\circledR}$ v.7.11, RSscan International) was used to detect the precise footprint length in millimetres. Footscan ${ }^{\circledR}$ pressure plate has shown good repeatability and is commonly

Table 1 Cross-sectional study population characteristics

\begin{tabular}{llll}
\hline & Total $(\boldsymbol{n}=\mathbf{2 2 7})$ & Males $(\mathbf{n}=\mathbf{2 1 3})$ & Females $(\boldsymbol{n}=\mathbf{1 4})$ \\
\hline Age, years (SD) $^{\mathrm{a}}$ & $29.5(7.2)$ & $29.4(7.0)$ & $32.1(8.3)$ \\
Service time, years (SD) & $7.2(6.4)$ & $7.1(6.4)$ & $8.3(6.5)$ \\
History of total lower extremity overuse injury, \% (n) & $42.7(n=97)$ & $43.2(n=92)$ & $35.7(n=5)$ \\
History of lower leg and foot overuse injury, \% (n) & $15.0(n=34)$ & $15.0(n=32)$ & $14.3(n=2)$ \\
Foot blisters after long marching, \% ( $n)$ & $46.3(n=105)$ & $46.5(n=99)$ & $42.9(n=6)$ \\
Usage of foot orthotics, \% ( $n)$ & $4.9(n=11)$ & $4.7(n=10)$ & $7.1(n=1)$ \\
\hline
\end{tabular}

${ }^{a}$ Standard deviation (SD) is given in brackets

Table 2 Case-control study population characteristics

\begin{tabular}{|c|c|c|c|c|}
\hline & Total $(n=66)$ & $\begin{array}{l}\text { Subjects with prior } \mathrm{OI}^{\mathrm{a}} \\
(\mathrm{n}=32)\end{array}$ & $\begin{array}{l}\text { Non-injured subjects } \\
(n=34)\end{array}$ & $P$ value $^{\mathrm{b}}$ \\
\hline Age, years & $29.7(5.5)$ & $29.0(5.7)$ & $30.5(5.3)$ & 0.12 \\
\hline Height, m (SD') & $1.81(0.13)$ & $1.81(0.13)$ & $1.81(0.13)$ & 0.96 \\
\hline Weight, kg (SD) & $81.3(12.9)$ & $81.3(13.3)$ & $81.2(12.6)$ & 0.96 \\
\hline Foot length, mm (SD) & $274(13)$ & $275(13)$ & $273(13)$ & 0.19 \\
\hline Usage of foot orthotics, \% (n) & $(n=4)$ & $12.5(n=4)$ & 0 & 0.04 \\
\hline Foot blisters after long marching, $\%$ (n) & $57.6(n=38)$ & $53.1(n=17)$ & $61.8(n=21)$ & 0.16 \\
\hline Foot skin lesions, \% (n) & $(n=14)$ & $(n=6)$ & $(n=8)$ & 0.58 \\
\hline Toenail problems, $\%(n)$ & $(n=18)$ & $(n=14)$ & $(n=4)$ & 0.01 \\
\hline
\end{tabular}

${ }^{\mathrm{a}} \mathrm{OI}$ - overuse injury. ${ }^{\mathrm{b}}$ One-way ANOVA test results; significant results are marked in bold. ${ }^{\mathrm{C}}$ Standard deviation (SD) is given in brackets 
used in foot pressure and foot area data assessment [26, 27]. To detect the correct shoe size, bare footprint length was converted to shoe size using the metric footwear sizing - Mondopoint system [28]. In the case of footprint length difference, the longer foot was chosen to analyse footwear sizing. A comparison of the used self-selected shoe size with a correct shoe size was made according to the bare footprint length. The correct fit was defined if the self-selected footwear size matched the Mondopoint sizing.

The size of issued military boots was self-selected based on soldier's previous shoe fitting experience; each size has only one width and half-sizes have not been provided. The footprint width was not analysed. Given that Latvia's average annual air temperature is $+5.9^{\circ} \mathrm{C}$ [29], and for most of the year soldiers use boots for hot weather conditions, we assessed the footwear comfort rating for this type of issued infantry boot only.

Statistical analysis was performed using the SPSS 22.0 software package (Statistical Package for the Social Sciences). Data were explored for distribution; normality was investigated using the Kolmogorov-Smirnov test. If data did not meet normal distribution assumptions, nonparametric tests were applied. Quantitative variables are presented as means with standard deviation; categorical variables are presented as frequencies if not stated otherwise. The study sample was defined as an "availability sample". Sample size calculations were based on one-year musculoskeletal lower extremity injury among Latvian Land Forces (12.4\%) and performed using the opensource calculator (OpenEpi, Open Source Statistics for Public Health) [30, 31]. The significance level was set to $p<0.05$ (two-tailed), and statistical power was set to 0.9 .

\section{Results}

\section{Footwear comfort rating}

Footwear comfort rating was assessed for all study participants $(n=227)$. Differences in footwear comfort rating between gender groups were independent of the previous history of overuse injury. The highest overall footwear comfort rating was 6.7 in the non-injured males group. The lowest rating of 5.2 was observed for the heel cushioning among the non-injured females group. Mean footwear comfort ratings among females were lower across all dimensions, but the difference with the male group was not statistically significant (see Table 3).

\section{Footwear sizing analysis}

In total, $n=66$ male subjects were additionally tested to assess the relationship between footwear comfort and lower leg overuse injury. For the additionally tested group, self-selected military footwear sizes were converted to $\mathrm{mm}$ (millimetres) using the Mondopoint system and then compared with the footprint length measurement from the Footscan ${ }^{\circledR}$ software. As a result, $57.6 \%(n=38)$ of all study subjects daily were wearing an inappropriate shoe size: $30.3 \%$ among subjects with a history of overuse injury $(n=20)$ and $27.3 \%$ among subjects without a history of overuse injury $(n=18)$. Only six subjects wore bigger shoe sizes, and others $(n=31)$ used a smaller shoe size than would be recommended according to their foot measurement. Self-selected shoe sizes were statistically significantly different among groups $(p=0.04)$. The median footprint length difference between the left and right sides was $1 \mathrm{~mm}$ (range $0-5 \mathrm{~mm}$ ). See Table 4 for details.

\section{Lower extremity overuse injury and comfort rating}

Subjects who wore the wrong shoe size in both (injured and non-injured) groups showed lower military footwear perceived comfort ratings across all dimensions, independent of previous lower extremity overuse injury. For most of the comfort dimensions, the difference between injured and non-injured groups was statistically significant. Detailed results are shown in Table 5.

Table 3 Mean military footwear comfort ratings

\begin{tabular}{|c|c|c|c|c|c|}
\hline & \multicolumn{2}{|l|}{ Males $(n=213)$} & \multirow{2}{*}{$\begin{array}{l}\text { Females }(n=14) \\
\text { With prior } \mathrm{OI}^{\mathrm{a}}(\mathrm{n}=5)\end{array}$} & \multirow{2}{*}{$\begin{array}{l}P \text {-value } \\
\text { Non-injured }(n=9)\end{array}$} & \\
\hline & $\begin{array}{l}\text { With prior } \mathrm{OI}^{\mathrm{a}} \\
(\mathrm{n}=92)\end{array}$ & $\begin{array}{l}\text { Non-injured } \\
(n=121)\end{array}$ & & & \\
\hline Overall comfort & $6.3(1.8)^{b}$ & $6.7(1.7)$ & $5.6(2.1)$ & $6.1(2.2)$ & 0.16 \\
\hline Forefoot cushioning & $6.0(1.9)$ & $6.4(1.8)$ & $5.6(1.7)$ & $5.7(2.0)$ & 0.12 \\
\hline Arch cushioning & $6.1(1.8)$ & $6.2(2.0)$ & $5.6(1.8)$ & $6.1(1.7)$ & 0.67 \\
\hline Heel cushioning & $6.2(1.8)$ & $6.2(2.0)$ & $5.6(1.3)$ & $5.2(2.0)$ & 0.84 \\
\hline Arch support & $6.0(1.9)$ & $6.4(1.9)$ & $6.0(1.7)$ & $5.7(1.9)$ & 0.19 \\
\hline Heel support & $6.2(1.9)$ & $6.7(1.8)$ & $5.8(1.6)$ & $6.0(2.4)$ & 0.05 \\
\hline
\end{tabular}

${ }^{\mathrm{a}} \mathrm{OI}$ - overuse injury; ${ }^{\mathrm{b}}$ Standard deviations are given in brackets; ${ }^{\mathrm{c}}$ One-way ANOVA test results comparing injured and non-injured groups 
Table 4 Military footwear sizing preferences

\begin{tabular}{|c|c|c|c|c|}
\hline & Total $(n=66)$ & $\begin{array}{l}\text { Subjects with prior } \mathrm{OI}^{\mathrm{a}} \\
(\mathrm{n}=32)\end{array}$ & $\begin{array}{l}\text { Non-injured subjects } \\
(n=34)\end{array}$ & $P_{\text {value }}{ }^{b}$ \\
\hline Self-selected EU ${ }^{d}$ shoe size, $\left(S^{c}\right)$ & $43(1.5)$ & $43.5(1.6)$ & $43(1.4)$ & 0.04 \\
\hline Measured EU shoe size, (SD) & $43.6(1.6)$ & $43.9(1.6)$ & $43.4(1.5)$ & $<0.01$ \\
\hline Suitable shoe size usage, \% (n) & $42.4(n=28)$ & $37.5(n=12)$ & $47.1(n=16)$ & 0.16 \\
\hline Inappropriate shoe size usage, \% (n) & $57.6(n=38)$ & $62.5(n=20)$ & $52.9(n=18)$ & \\
\hline
\end{tabular}

${ }^{a} \mathrm{Ol}$ - overuse injury. ${ }^{b} \mathrm{Chi}$-square test results; significant results are marked in bold. ${ }^{\mathrm{c}} \mathrm{Standard}$ deviation (SD) is given in brackets

${ }^{d}$ EU - European shoe size

Table 5 Military footwear comfort rating comparison among study subjects

\begin{tabular}{|c|c|c|c|c|c|c|}
\hline & \multicolumn{2}{|c|}{$\begin{array}{l}\text { Subjects wearing inappropriate shoe sizes } \\
(n=38)\end{array}$} & \multicolumn{2}{|c|}{ Subjects wearing suitable shoe sizes $(n=28)$} & \multirow[t]{2}{*}{$x^{2}(1)$} & \multirow[t]{2}{*}{ Pvalue $^{\dagger}$} \\
\hline & $\begin{array}{l}\text { With prior OI } \\
(n=20)\end{array}$ & Non-injured $(n=18)$ & $\begin{array}{l}\text { With prior OI } \\
(n=12)\end{array}$ & Non-injured $(n=16)$ & & \\
\hline Overall comfort & $6.69(1.22)$ & $6.91(1.11)$ & $7.29(1.04)$ & $7.28(1.33)$ & 5.23 & 0.02 \\
\hline Forefoot cushioning & $6.24(1.57)$ & $6.18(1.78)$ & $7.00(0.98)$ & $6.59(1.72)$ & 4.17 & 0.04 \\
\hline Arch cushioning & $6.24(1.57)$ & $6.15(1.79)$ & $6.88(1.36)$ & $6.53(2.00)$ & 3.61 & 0.06 \\
\hline Heel cushioning & $6.29(1.38)$ & $6.26(1.52)$ & $6.92(1.38)$ & $6.66(1.66)$ & 5.06 & 0.03 \\
\hline Arch support & $5.90(1.79)$ & $6.15(1.74)$ & $6.75(1.59)$ & $6.63(1.88)$ & 4.38 & 0.04 \\
\hline Heel support & $6.38(1.61)$ & $6.47(1.58)$ & $7.58(1.02)$ & $7.19(1.18)$ & 11.07 & $<0.01$ \\
\hline
\end{tabular}

$\mathrm{OI}$ - overuse injury. ${ }^{\dagger}$ Kruskal Wallis test results; standard deviation is given in brackets. Significant results are marked in bold

\section{Discussion}

To the author's knowledge, this is the first attempt to systematically evaluate perceived footwear comfort for different boot dimensions in a relationship with previous foot overuse injury among infantry soldiers. The present study assessed military boot comfort ratings and footwear fit among infantry soldiers with and without a history of lower extremity overuse injury. However, the overuse injury definition used widely is not uniform, we used the definition that emphasises a mechanism of gradual onset and underlying pathogenesis of repetitive microtrauma as was recommended by Roos et al. [32] Previous military footwear research performed in 1976 focused on different lower extremity disorders, both acute (ankle fractures) and overuse injuries (heel contusions, toe paresthesia, and retrocalcaneal bursitis), and military boot comfort data for different boot dimensions remained unknown $[19,20]$. According to Dijksma et al. findings of previous footwear research among military populations may no longer apply due to the design of military boots evolving [33]. Current military boot design should contribute to better perceived comfort and a standardised military footwear comfort evaluation tool is needed.

Footwear comfort measures are difficult to compare with other studies due to methodological differences. Perceived comfort perception in our study was measured using a visual analogue scale, not only for overall comfort but also for cushioning and supporting different parts of the foot [24]. Muniz et al. only reported overall footwear comfort among Brazilian army recruits that varied from 5.5 to 7.7 points, with higher comfort provided by softer midsole and lower boot weight [34]. Paisis et al. investigated perceived comfort among the Greek army, and study results showed that participants also preferred walking with the lightest weight boot. It has been reported that reduced weight, increased stiffness, and the construction of military boots could be beneficial for higher footwear comfort [35]. Types of military footwear materials, shock-absorbing possibilities, microclimate features, footwear width, and footwear weight, as well as gait kinematics, were not assessed in our study.

Footwear sizes in the Latvian Land Forces are selfselected by the soldier. Footwear sizes vary among producers, and the soldier's choice of footwear size is based on previous experience, which can be wrong. Study findings conducted among infantry of Canadian Land Forces showed that personnel footwear was not appropriately fitted according to foot length and width [36].

We compared self-selected footwear sizes with recommended footwear sizes (based on footprint length). We used a universal Mondopoint footwear size measurement system for size conversion, which is performed on a statistically constructed human foot and uses foot length in 
millimetres. Our study findings showed that $56 \%$ of study participants wore inappropriate shoe sizes, and these results are consistent with the previously mentioned study [36]. Wearing incorrectly sized footwear is a common problem, and it has been associated with foot pain and foot disorder [13]. The shoe's fit has been associated with skin disorders of the foot such as corns and calluses. In our study, foot skin disorders were not prevalent among both study groups, and recently it has been proposed that corns and calluses could indicate the asymmetrical behaviour of the lower limbs during gait [37]. Toenail disorders, which could result from the tight toe box of footwear [25], were more prevalent among subjects with prior overuse injury who used an inappropriate shoe size. Highly rated footwear comfort is possible if the proper fit is provided, and our study results show moderately low comfort ratings.

Study subjects who used inappropriate shoe sizes showed statistically significantly lower military footwear perceived comfort ratings across all dimensions, and these results are partly consistent with previous findings. It has been reported that inappropriate shoe fit could lead to discomfort and contribute to lower extremity overuse injury due to gait adaptations [38]. However, the complexity of what makes the appropriately fitted shoe more comfortable, and the impact of shoe comfort on gait and pathology is not yet well understood [39].

Our study results found no relationship between footwear comfort ratings and lower extremity injury history. Grier et al. have identified that better cushioned footwear did not lower injury incidence, although poor footwear fit and cushioning were associated with foot pain and discomfort. Our study results showed that subjects wearing the wrong shoe size reported lower footwear comfort ratings. To potentially increase footwear cushioning and comfort shock-absorbing insoles have been recommended $[8,40]$. Prefabricated foot orthoses were found to be effective in preventing lower limb overuse injuries [41].

Current study findings should be considered in the context of study limitations. The cross-sectional study design is a limitation due to the inability to establish causal sequences and recall bias of injury history. Although the study population is relatively small, it is representative $(n=227)$ and considerably larger than calculated sample size $(n=150)$. Grouping of the casecontrol study also depends on participant honesty, and it has been reported that approximately half of the injuries among military populations are not usually reported to medical personnel [42]. We believe that answers to the interviewer were honest because soldiers were informed that the study results would not affect the medical annual check-up status. Also, comfort ratings could influence the fact that only one type of infantry boot (for hot weather conditions) was assessed. Additionally, including foot width could provide more detailed comfort ratings, but since it did not impact boot size measurements, it was not included in the analysis. We did not check if the same boot pair was used for the last 6 months; however, all soldiers of the Land Forces of Latvia use the same boot model, and in any case, comfort ratings were provided for the same boot model. Given that perceived footwear comfort rating could change during physical activity due to fatigue [43], our study participants rated footwear comfort during a day-off to avoid the possible skewing of comfort data. The use of Footscan ${ }^{\circledR}$ software for foot length measurement was selected as reliable since digital footprint measurement for foot length assessment was found to be similar to a 3D (three-dimensional) foot scan [44]. Despite these limitations, the strength of this research is that it comes from a relatively homogeneous population and helps to gain a deeper understanding of military footwear fit and comfort by comparing previously injured and non-injured infantry soldiers groups.

According to our study, proper fit is an essential factor that leads to more comfortable military footwear usage. It is recommended to issue adequate military footwear size according to foot dimension measurement using a Brannock device or 3D foot scan to provide better footwear comfort. The findings of this study can also provide valuable information on footwear comfort to other users of work boots.

\section{Conclusions}

To the authors' knowledge, this is the first study of subjective infantry boot fit and comfort among infantry soldiers considering a history of lower extremity overuse injury. Study results showed that inappropriate infantry boot size significantly affects footwear comfort ratings. History of previous lower extremity overuse injury was not related to either shoe size selection or footwear comfort ratings. Based on our study results, we recommend footprint length assessment for proper footwear size selection.

\section{Abbreviations \\ ICD-10: International Classification of Diseases; : Tenth Revision; SPSS: Statistical Package for the Social Sciences; mm: millimetres; 3D: three-dimensional.}

\section{Supplementary Information}

The online version contains supplementary material available at https://doi.
org/10.1186/s12891-021-04839-9.

Additional file 1."Military_boot_comfort_tool.pdf", example of visual analogue scale used for footwear comfort assessment. 


\section{Acknowledgments}

The authors would like to thank the soldiers who participated in the study and the Latvian National Army Logistic Command Military Medical Support Centre for the support.

\section{Authors' contributions}

DN contributed to the whole study (research design, literature review, data collection and analysis, writing the manuscript). NV contributed to research design and data collection. AS contributed to data analysis and manuscript writing. All the authors read and approved the final manuscript.

\section{Funding}

This research was financially supported by a Rīga Stradinš University doctoral research grant.

\section{Availability of data and materials}

Datasets analysed in this study are not publicly available because the Latvian National Army Logistic Command Military Medical Support Centre did not permit data sharing. Request to access the datasets should be directed to the corresponding author.

\section{Declarations}

\section{Ethics approval and consent to participate}

Participation was voluntary. All study participants provided written informed consent. Ethical approval was obtained from the Ethics Committee of Riga Stradinš University (No. 40/26.10.2017).

\section{Consent for publication}

Not applicable.

\section{Competing interests}

The authors have no competing interests to declare.

\section{Author details}

'Military Medicine Research and Study Centre, Rīga Stradiņš University, 14 Baložu Street, Riga LV-1048, Latvia. ${ }^{2}$ Latvian National Armed Forces Joint Headquarters Medical Service, Kadaga 2103, Latvia.

Received: 20 June 2021 Accepted: 4 November 2021 Published online: 15 November 2021

\section{References}

1. Taanila H, Suni JH, Kannus P, Pihlajamäki H, Ruohola J-P, Viskari J, et al. Risk factors of acute and overuse musculoskeletal injuries among young conscripts: a population-based cohort study. BMC Musculoskelet Disord. 2015;16:104. https://doi.org/10.1186/s12891-015-0557-7.

2. Lovalekar M, Johnson CD, Eagle S, Wohleber MF, Keenan KA, Beals K, et al. Epidemiology of musculoskeletal injuries among US air force special tactics operators: an economic cost perspective. BMJ Open Sport Exerc Med. 2018;4:e000471. https://doi.org/10.1136/bmjsem-2018-000471.

3. Jamal A, Ali MK, Mirza TM, Raza M, Access O, Related S, et al. Patterns of stress related injuries of lower limbs in military setup on skeletal scintigraphy. Pak Armed Forces Med J. 2016;66:742-6.

4. Hauschild VD, Schuh-Renner A, Lee T, Richardson MD, Hauret K, Jones BH. Using causal energy categories to report the distribution of injuries in an active population: an approach used by the U.S. Army. J Sci Med Sport. 2019;22:997-1003.

5. Fredette MA, Roy J-S, Esculier J-F, ois, Perreault K. Most military runners report recent changes in running parameters before lower limb injury onset. Mil Med. 2020. https://doi.org/10.1093/milmed/usaa524.

6. Lovalekar M, Hauret K, Roy T, Taylor K, Blacker SD, Newman P, et al. Musculoskeletal injuries in military personnel-descriptive epidemiology, risk factor identification, and prevention. J Sci Med Sport. 2021;24:963-9. https://doi.org/10.1016/j.jsams.2021.03.016.

7. Milgrom C, Finestone A, Shlamkovitch N, Wosk J, Laor A, Voloshin A, et al. Prevention of overuse injuries of the foot by improved shoe shock attenuation. A randomized prospective study. Clin Orthop Relat Res. 1992:189-92.

8. Grier TL, Knapik JJ, Swedler D, Jones BH. Footwear in the United States Army band: injury incidence and risk factors associated with foot pain. Foot. 2011;21:60-5. https://doi.org/10.1016/j.foot.2010.12.002.

9. Milgrom C, Sorkin A, Gam A, Singer J, Nir I, Kogan B, et al. The search for the best infantry boot. Disaster Mil Med. 2016;2:14. https://doi.org/10. 1186/s40696-016-0024-5.

10. Miller JE, Nigg BM, Liu W, Stefanyshyn DJ, Nurse MA. Influence of foot, leg and shoe characteristics on subjective comfort. Foot Ankle Int. 2000;21:759-67.

11. West AM, Schönfisch D, Picard A, Tarrier J, Hodder S, Havenith G. Shoe microclimate: an objective characterisation and subjective evaluation. Appl Ergon. 2019;78:1-12.

12. Jordan C, Bartlett R. Relationship between plantar and dorsal pressure distribution and perception of comfort in casual footwear. Gait Posture. 1994;2:251.

13. Buldt AK, Menz HB. Incorrectly fitted footwear, foot pain and foot disorders: a systematic search and narrative review of the literature. J Foot Ankle Res. 2018;11:43.

14. Luximon A, Jiang L, Luximon Y. Sizing and grading methods with consideration of footwear styles. Int J Ind Ergon. 2020;78:102960.

15. Mayeaux EJ, Carter C, Murphy TE. Ingrown toenail management. Am Fam Physician. 2019;100:158-64.

16. Ganesan B, Prasad P, Akter S, Tong RKY. Common orthopedic problems in the foot and their implications for footwear design. In: Handbook of Footwear Design and Manufacture Elsevier; 2021. p. 413-438.

17. Nigg B, Baltich J, Hoerzer S, Enders H. Running shoes and running injuries: mythbusting and a proposal for two new paradigms: 'preferred movement path' and 'comfort filter.' Br J Sports Med 2015;49:1290-1294. doi:https://doi.org/10.1136/bjsports-2015-095054.

18. Willems TM, De Ridder R, Roosen P. Is consumer behaviour towards footwear predisposing for lower extremity injuries in runners and walkers? A prospective study. J Foot Ankle Res. 2019;12:43.

19. Bensel C. The effects of tropical and leather combat boots on lower extremity disorders among US Marine Corps Recruits 1976;:63. https:// apps.dtic.mil/sti/citations/ADA025938. Accessed 03 Mar 2021.

20. Bensel C, Kish R. Lower extremity disorders among men and women in Army basic training and effects of two types of Boots. 1983:99. https:// apps.dtic.mil/sti/citations/ADA133002. Accessed 03 Mar 2021.

21. World Health Organization. International statistical classification of diseases and related health problems, 10th revision (ICD-10). World Heal Organ. 2016.

22. Kernan M, Raja B, Matuszak J. The collegiate/professional male athlete. In: Heidelbaugh JJBT-CMH, editor. Clinical Men's health. Philadelphia: Elsevier; 2008. p. 485-522. https://doi.org/10.1016/B978-141603000-3. 10026-7.

23. Barell V. An introduction to the Barell body region by nature of injury diagnosis matrix. Inj Prev. 2002;8:91-6. https://doi.org/10.1136/ip.8.2.91.

24. Mills K, Blanch P, Vicenzino B. Identifying clinically meaningful tools for measuring comfort perception of footwear. Med Sci Sport Exerc 2010;42:1966-71. https://doi.org/10.1249/MSS.0b013e3181dbacc8.

25. Carr PC, Cropley TG. Sports dermatology: skin disease in athletes. Clin Sports Med. 2019;38:597-618. https://doi.org/10.1016/j.csm.2019.06.001.

26. Xu C, Wen $X-X$, Huang L-Y, Shang L, Cheng $X-X$, Yan Y-B, et al. Normal foot loading parameters and repeatability of the Footscan ${ }^{\circledR}$ platform system. J Foot Ankle Res. 2017;10:30. https://doi.org/10.1186/s13047-017-0209-2.

27. Takata Y, Kawamura R, Matsuoka S, Hashida H, Asano G, Kimura K, et al. Comparison of flatfeet and normal feet using data of the gait cycle, contact area, and foot pressure. Data Br. 2021;36:106990. https://doi.org/ 10.1016/j.dib.2021.106990.

28. Celko J. Chapter 20 - Shoe Sizes. In: Celko J, editor. Joe Celko's data, measurements and standards in SQL. Boston: Morgan Kaufmann; 2010. p. 167-168. doi:https://doi.org/https://doi.org/10.1016/B978-0-12-3747228.00020-7.

29. Latvian Environment, Geology and meteorology Centre. Climate of Latvia https://www.meteo.lv/en/lapas/environment/climate-change/climateof-latvia/climat-latvia?id=1471\&nid=660. Accessed 15 Oct 2017.

30. Nesteroviča D, Stepens A, Vaivads N. Peak plantar pressure as a risk factor for lower extremity overuse injury among infantry soldiers. Proc Latv 
Acad Sci Sect B Nat Exact, Appl Sci. 2021;75:52-7. https://doi.org/10. 2478/prolas-2021-0009.

31. Kelsey L, Fleiss K FP. Methods in observational Epidemiology 2nd Edition, Statistical Methods for Rates and Proportion, formulas 3.18 and 19. Methods in observational epidemiology 2nd edition, statistical methods for rates and proportion, formulas 3.18 and 19. 2010.

32. Roos KG, Marshall SW. Definition and usage of the term "overuse injury" in the US high school and collegiate sport epidemiology literature: a systematic review. Sport Med. 2014;44:405-21. https://doi.org/10.1007/ s40279-013-0124-Z.

33. Dijksma I, Arslan IG, van Etten-Jamaludin FS, Elbers RG, Lucas C, Stuiver MM. Exercise programs to reduce the risk of musculoskeletal injuries in military personnel: a systematic review and Meta-analysis. PM R. 2020;12:1028-37.

34. Muniz AMS, Bini RR. Shock attenuation characteristics of three different military boots during gait. Gait Posture. 2017;58 July:59-65. doi:https:// doi.org/10.1016/j.gaitpost.2017.07.037.

35. Paisis P, Hanley B, Havenetidis K, Bissas A. Cypriot and greek army military boot cushioning: ground reaction forces and subjective responses. Mil Med. 2013:178:e493-7.

36. DyckW. A study of the relationship between foot size and combat boot size in the Canadian forces. Defence and Civil Institute of Environmental Medicine, Defence R\&D Canada, DCIEM TR 2000-137, 2000; p. 1-31.

37. Grouios $\mathrm{G}$. Footedness as a potential factor that contributes to the causation of corn and callus formation in lower extremities of physically active individuals. Foot. 2005;15:154-62. https://doi.org/10.1016/j.foot.2005.05. 003.

38. Finestone A, Shlamkovitch N, Eldad A, Karp A, Milgrom C. A prospective study of the effect of the appropriateness of foot-shoe fit and training shoe type on the incidence of overuse injuries among infantry recruits. Mil Med. 1992;157:489-90. https://doi.org/10.1093/milmed/157.9.489.

39. Branthwaite $H$, Chockalingam N. Everyday footwear: an overview of what we know and what we should know on ill-fitting footwear and associated pain and pathology. Foot. 2019;39:11-4.

40. Lullini G, Giangrande A, Caravaggi P, Leardini A, Berti L. Functional evaluation of a shock absorbing insole during military training in a Group of Soldiers: a pilot study. Mil Med. 2020;185:e643-8. https://doi.org/10.1093/ milmed/usaa032.

41. Bonanno DR, Murley GS, Munteanu SE, Landorf KB, Menz HB. Effectiveness of foot orthoses for the prevention of lower limb overuse injuries in naval recruits: a randomised controlled trial. Br I Sports Med. 2018:52:298-302.

42. Smith L, Westrick R, Sauers S, Cooper A, Scofield D, Claro P, et al. Underreporting of musculoskeletal injuries in the US Army. Sport Heal A Multidiscip Approach. 2016;8:507-13. https://doi.org/10.1177/1941738116 670873.

43. Hintzy F, Cavagna J, Horvais N. Evolution of perceived footwear comfort over a prolonged running session. Foot. 2015;25:220-3. https://doi.org/ 10.1016/j.foot.2015.08.003.

44. Lee $Y-C$, Lin G, Wang M-JJ. Comparing 3D foot scanning with conventional measurement methods. J Foot Ankle Res 2014;7:44. doi:https://doi. org/10.1186/s13047-014-0044-7.

\section{Publisher's Note}

Springer Nature remains neutral with regard to jurisdictional claims in published maps and institutional affiliations.
Ready to submit your research? Choose BMC and benefit from:

- fast, convenient online submission

- thorough peer review by experienced researchers in your field

- rapid publication on acceptance

- support for research data, including large and complex data types

- gold Open Access which fosters wider collaboration and increased citations

- maximum visibility for your research: over 100M website views per year

At BMC, research is always in progress.

Learn more biomedcentral.com/submissions 